\title{
Genetic and Metabolic Determinants of Plasminogen Activator Inhibitor 1 (PAI-1) in Tunisian Type 2 Diabetes Patients
}

\author{
Mohamed Moustapha ${ }^{1}$, Molka Chadhli-Chaieb², Touhami Mahjoub ${ }^{3}$, Larbi Chaieb ${ }^{2}$ \\ ${ }^{1}$ Internal Medicine Department, Hospital Cheikh Zayed, Nouakchott, Mauritania \\ ${ }^{2}$ Endocrinology Department, CHU Farhat Hachad Sousse, Sousse, Tunisia \\ ${ }^{3}$ Research Unit of Biology, Genetics of Cancers, Haematological and Autoimmune Diseases, Faculty of Pharmacy of Monastir, \\ University of Monastir, Monastir, Tunisia \\ Email: *ouldhayani@gmail.com
}

How to cite this paper: Moustapha, M., Chadhli-Chaieb, M., Mahjoub, T. and Chaieb, L. (2017) Genetic and Metabolic Determinants of Plasminogen Activator Inhibitor 1 (PAI-1) in Tunisian Type 2 Diabetes Patients. Open Journal of Endocrine and Metabolic Diseases, 7, 141-150. https://doi.org/10.4236/ojemd.2017.76013

Received: June 1, 2017

Accepted: June 27, 2017

Published: June 30, 2017

Copyright $\odot 2017$ by authors and Scientific Research Publishing Inc. This work is licensed under the Creative Commons Attribution International License (CC BY 4.0).

http://creativecommons.org/licenses/by/4.0/

\begin{abstract}
Background: PAI-1 (plasminogen activator inhibitor-1) is a powerful regulator of fibrinolysis and plasma level is high in type 2 diabetes and cardio-vascular disease, which is determined by genetic polymorphisms in PAI-1 gene and environmental factors. The aim of the study was to examine the determinants of plasma PAI-1 Ag level among type 2 diabetes patients. Methods: 491 Tunisian type 2 diabetes patients had clinical evaluation (weight, high, BMI, Waist Circumference), laboratory investigations including FBG $\mathrm{Hb} 1 \mathrm{Ac}$, cholesterol, triglyceride; HDL-cholesterol was done; plasma PAI-1 antigen level was done with ELISA; -675 4G/5G and -844 G/A polymorphisms of PAI-1 gene was done by PCR-ASA and PCR-RFLP respectively. Results: The mean age for our patients was $58.3 \pm 10.5$ years; sex-ratio $=0.92$; mean PAI-1 level was $34.6 \pm 21.3 \mathrm{ng} / \mathrm{ml}$. We didn't find correlation between PAI-1 level and BMI, but we have found significant correlation between PAI-1 and waist circumference $(p=0.032)$, most enhanced in men $(P=0.002)$, T2D patients who have FBG $>11 \mathrm{mmol} / \mathrm{l}$ had PAI-1 Ag level higher than those who have $\mathrm{FBG}<11 \mathrm{mmol} / \mathrm{l}(P=0.034)$, but no difference found between T2D with high $\mathrm{Hb} 1 \mathrm{Ac}>8 \%$ and those with $\mathrm{Hb} 1 \mathrm{Ac}<8 \%$, significant correlation was seen between PAI-1 level and LDL-cholesterol $(P=0.05)$, high correlation between PAI-1 Ag level and -675 4G/5G polymorphism genotype was seen, $4 \mathrm{G} / 4 \mathrm{G}$ carriers had the highest PAI-1 level, 4G/5G had intermediary level and 5G/5G had the lowest level $(P<0.001)$. No correlation was seen between PAI-1 Ag level and -844G/A polymorphism genotypes. Using multiple variable linear regression analysis, the independent factor associated with plasma PAI-1 level was $-6754 \mathrm{G} / 5 \mathrm{G}$ polymorphism (regression coefficient $\beta=4.6, P$
\end{abstract}


$<0.01)$. Conclusion: the present study identifies $-6754 \mathrm{G} / 5 \mathrm{G}$ not $-844 \mathrm{G} / \mathrm{A}$ polymorphism of PAI gene as the principal determinant of plasma PAI-1 level in Tunisian T2D patients, the android fat distribution, dyslipidemia and hyperglycemia play a modest role in this variation.

\section{Keywords}

Plasminogen Activator Inhibitor 1, Polymorphism, PCR, Type 2 Diabetes Mellitus, Metabolic Syndrome X

\section{Introduction}

Most patients with type 2 diabetes (T2D) die from complication of atherosclerosis [1].

PAI-1 (plasminogen activator inhibitor-1) is a major regulator of fibrinolysis [2], plasma PAI-1 Antigen (PAI-1Ag) level is increased in type 2 diabetes patients [3] [4] and that may explain excess risk of cardiovascular disease. It also elevated in coronary artery disease patients [5] and its plasma level is determined by genetic [6] and environmental factors [7].

The PAI-1 gene has been localized to q21.3-q22 of chromosome 7 [8]. Several polymorphisms within the PAI-1 gene influence PAI-1 levels [9]. The most known polymorphism which influences PAI-1 level is $-6754 \mathrm{G} / 5 \mathrm{G}$ insertion-deletion mutation-of PAI-1 promotor gene [6] and another single nucleotide polymorphism is $-844 \mathrm{G} / \mathrm{A}$ [10] [11] [12].

Environmental factors, like obesity and metabolic syndrome features also plays a role in Plasma PAI-1 variation in type 2 diabetes patients and in non diabetics [7] [13]. The aim of this study was to examine the determinants of plasma PAI-1 Ag level among adult patients with type 2 diabetes in Tunisia.

\section{Patients and Methods}

This was a cross sectional study involving 491 type 2 diabetic patients recruited from the outpatient's endocrinology department at Farhat-Hachad hospital in Sousse-Tunisia during 2005-2006 period, written informed consent was obtained from participants, the study was approved by hospital ethic comity, inclusion criteria was: known type 2 diabetes, exclusion criteria were: cancer, coagulation disorders, pregnancy, end stage chronic kidney disease, all patients had clinical examination including (weight, high, BMI, Waist Circumference (WC)), laboratory investigations (Fasting blood glucose (FBG), Hb1 Ac, cholesterol, triglyceride, HDL-cholesterol,) LDL was calculated by Fridewald formula(LDL (mmol/l) $=$ total cholesterol $-\mathrm{HDL}-\mathrm{TG} / 2.26)$, after clear write consent plasma PAI-1 antigen level was done with ELISA, -675 4G/5G. PAI-1 gene promoter polymorphism genotyping was done by PCR-ASA(allele specific amplification) using common primer for 2 alleles in 5'P side and 2 specific primers for 2 alleles in 3'OH side and $-844 \mathrm{G} / \mathrm{A}$ polymorphism genotyping was done by PCR-RFLP 
(restriction fragment length polymorphism) using 2 specific primers for 2 alleles and DNA was digested with restriction enzyme, allelic frequency was calculated with hardy-Weinberg law $(p+q)^{2}=p^{2}+2 p q+q^{2}=1$, with $p=\mathrm{n} 1+\mathrm{n} 2 / 2 \mathrm{n}$ and $q$ $=\mathrm{n} 3+\mathrm{n} 2 / 2 \mathrm{n}, \mathrm{n}=$ number total of patients, $\mathrm{n} 1=4 \mathrm{G} / 4 \mathrm{G}$ carriers, $\mathrm{n} 2=4 \mathrm{G} / 5 \mathrm{G}$, and $\mathrm{n} 3=5 \mathrm{G} / 5 \mathrm{G}, P=$ allele $4 \mathrm{G}$ frequency, $q=5 \mathrm{G}$ frequency. The same procedure was made with $-844 \mathrm{G} / \mathrm{A}$, and statistical analyses was performed using SPSS version 10.0 software.

\section{Results}

The mean age of our $\mathrm{T} 2 \mathrm{D}$ population was $58.3 \pm 10.5$ years, male/female-ratio $=$ 0.92 , mean PAI-1 level was $34.6 \pm 21.3 \mathrm{ng} / \mathrm{ml}$.

Table 1 shows PAI-1Ag level was not correlated with BMI, but was significantly correlated with waist circumference $(P=0.032)$, this correlation was most evidenced in men $(P=0.002)$ (Table 2$)$.

No significant difference found in PAI-1 Ag level between type 2 diabetes patients with hypertension and T2D without hypertension (Table 3).

In multivariate analysis, we found significant relationship between PAI-1 level and LDL-cholesterol $(P=0.05)$ (Figure 1).

T2D patients who have FBG $>11 \mathrm{mmol} / \mathrm{l}$ had PAI-1 Ag level higher than those who have $\mathrm{FBG}<11 \mathrm{mmol} / \mathrm{l}(P=0.034)$, but no difference found between T2D with high Hb1Ac $>8 \%$ and those with Hb1 Ac $<8 \%$ (Table 4).

The Table 5 shows high correlation between PAI-1 Ag level and -675 4G/5G polymorphism genotypes, 4G/4Gcarriers had the highest PAI-1 level, 4G/5G had intermediary level and 5G/5G had the lowest level $(P<0.001)$, No correlation was seen between PAI-1 Ag level and -844G/A polymorphism genotypes.

Using multiple variable linear regression analysis, the independent factor associated with plasma PAI-1 level was $-6754 \mathrm{G} / 5 \mathrm{G}$ polymorphism (regression coefficient $\beta=4.6, P<0.05)$.

Table 1. PAI-1 Ag level in diabetics in function of BMI $\left(\mathrm{kg} / \mathrm{m}^{2}\right)$.

\begin{tabular}{ccccc}
\hline PAI-1 $(\mathrm{ng} / \mathrm{ml})$ & $\mathrm{BMI}<25$ & $25<\mathrm{BMI}<30$ & $\mathrm{BMI}>30$ & $P$ \\
\hline Mean $\pm \mathrm{SD}$ & $34.1 \pm 21.4$ & $35 \pm 20.6$ & $34.7 \pm 22$ & NS \\
$($ Range $)$ & $(11-88.9)$ & $(11-92)$ & $(10-111)$ & \\
\hline
\end{tabular}

SD: Standard Deviation; $P$. P-Value; NS: Non Significant.

Table 2. Mean PAI-1 Ag level in type 2 diabetes patients in function of WC $(\mathrm{cm})$ and sex.

\begin{tabular}{|c|c|c|c|c|}
\hline \multirow{4}{*}{$\begin{array}{c}\text { PAI-1 Ag } \\
(\text { Mean } \pm \text { SD) }\end{array}$} & \multicolumn{4}{|c|}{$\mathrm{WC}(\mathrm{cm})$} \\
\hline & \multicolumn{2}{|c|}{ Men } & \multicolumn{2}{|c|}{ Women } \\
\hline & $\mathrm{WC}<102 \mathrm{~cm}$ & $\mathrm{WC}>102 \mathrm{~cm}$ & $\mathrm{WC}<88 \mathrm{~cm}$ & $\mathrm{WC}>88 \mathrm{~cm}$ \\
\hline & $29.717 .7 \mathrm{ng} / \mathrm{ml}$ & $44.3 \pm 22.3 \mathrm{ng} / \mathrm{ml}$ & $35.3 \pm 22.4 \mathrm{ng} / \mathrm{ml}$ & $33.5 \pm 18.4 \mathrm{ng} / \mathrm{ml}$ \\
\hline$P$ & \multicolumn{2}{|c|}{$<0.001$} & \multicolumn{2}{|c|}{ NS } \\
\hline
\end{tabular}

SD: Standard Deviation; P. P-Value; NS: Non Significant. 


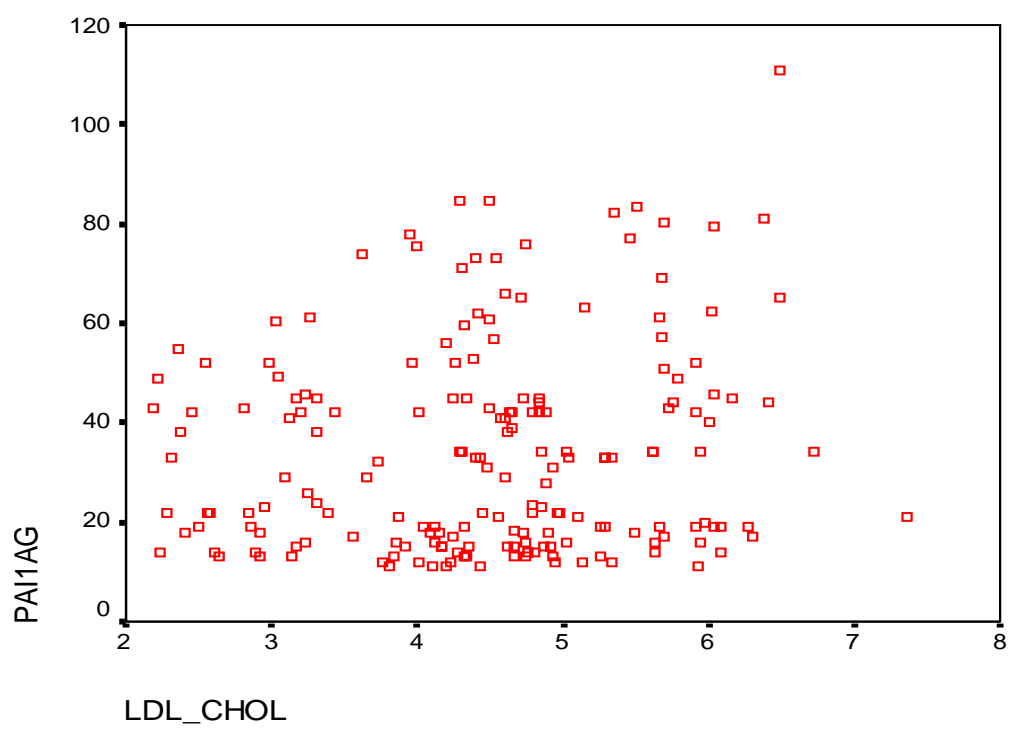

Figure 1. MeanPAI-1-Ag in relation to LDL in T2D patients.

Table 3. Mean PAI-1 Ag level in T2D patients in function of hypertension.

\begin{tabular}{cccc}
\hline PAI-1 $(\mathrm{ng} / \mathrm{ml})$ & $\begin{array}{c}\text { T2D with hypertension } \\
(\mathrm{n}=197)\end{array}$ & $\begin{array}{c}\text { T2D without hypertension } \\
(\mathrm{n}=294)\end{array}$ & $P$ \\
\hline Mean \pm SD (range) & $33.7 \pm 21.7(11-92)$ & $35.3 \pm 20.9(10-111)$ & NS
\end{tabular}

SD: Standard Deviation; $P$. $P$-Value; NS: Non Significant.

Table 4. Mean PAI-1 Ag in T2D in function of FBG (fast blood glucose) and Hb1Ac.

\begin{tabular}{|c|c|c|c|}
\hline \multirow{2}{*}{ PAI-1 (ng/ml) } & \multicolumn{2}{|c|}{ FBG } & \multirow{2}{*}{$P$} \\
\hline & $<11 \mathrm{mmol} / \mathrm{l}$ & $>11 \mathrm{mmol} / \mathrm{l}$ & \\
\hline Mean \pm SD & $32.2 \pm 20.6$ & $36.5 \pm 21.5$ & 0:034 \\
\hline \multicolumn{4}{|c|}{$\mathrm{Hb} 1 \mathrm{Ac}$} \\
\hline & $<8 \%$ & $>8 \%$ & \\
\hline Mean \pm SD & $35.4 \pm 21.2$ & $34 \pm 21.3$ & NS \\
\hline
\end{tabular}

SD: Standard Deviation; P. P-Value; NS: Non Significant.

Table 5. Correlation between PAI-1 -Ag level and -675 4G/5G and -844G/A genotypes in T2D patients.

\begin{tabular}{ccc}
\hline Génotype & $\begin{array}{c}\text { PAI-1 (ng/ml) } \\
\text { Mean } \pm \text { SD (range) }\end{array}$ & $P$ \\
\hline $4 \mathrm{G} / 4 \mathrm{G}$ & $59.4 \pm 18.7(31-111)$ & $<0.001$ \\
$4 \mathrm{G} / 5 \mathrm{G}$ & $35.2 \pm 20.6(11-89.6)$ & \\
$5 \mathrm{G} / 5 \mathrm{G}$ & $23 \pm 11.4(10-56)$ & \\
A/A & $34.8 \pm 21.7(11-111)$ & NS \\
G/A & $35.8 \pm 21.8(10-89)$ & \\
G/G & $32.7 \pm 20(11-89.6)$ &
\end{tabular}

P. $P$-Value; NS: Non Significant. 


\section{Discussion}

PAI-1 level is increased in type 2 diabetic patients [3] [8] [14] [15] [16] in comparison with non diabetic.

In IRAS (insulin resistance atherosclerosis study) [17] high level of PAI-1 was a predictor of type 2 diabetes incidence, in multiple regression analyses, PAI- 1 level still significantly linked to type 2 diabetes incidence. In the same study high PAI-1 level was linked to diabetes incidence. [18], In Health, Aging and Body Composition Study [19] similar results were found.

In Framingham Offspring Study [20], high PAI-1level was a risk factor of type 2 diabetes with relative risk (RR) of 1.4 for people who have PAI-1 level in upper normal range, this risk is independent of obesity and classical risk factors. In Strong Heart Study [21], relationship between PAI-1 level and diabetes incidence was found but this relationship become non-significant after adjustment with other variables (age, sex, BMI, BP, triglyceride, CRP, fibrinogen and insulin), antidiabetic drug vildagliptin decrease PAI-1 level [22].

A recent metanalysis [23] shows moderate association between PAI-1 and T2D independent of established diabetes risk factors.

In our study mean PAI-1 Ag level was $34.6 \pm 21.4 \mathrm{ng} / \mathrm{ml}$. we didn't have control group due to financial limits (cost of dosage) and the comparison with other studies is difficult because measurements methods are different and non-standardized.

The PAI-1 level is correlated to insulin resistance markers (BMI, Waist circumference, glucose level and insulin) [4] [24].

In our study we didn't find a positive correlation between BMI and PAI-1 but we found correlation between PAI-1 and WC which was most evident in men.

We had found correlation between PAI-1 and LDL cholesterol, LDL and VLDL cholesterol stimulate PAI-1 gene expression in vitro [8], that may explain this correlation

The patients who have FBG $>11 \mathrm{mmol} / \mathrm{l}$ have PAI- 1 level more than patients who have $\mathrm{FBG}<11 \mathrm{mmol} / \mathrm{l}$.

Glucose stimulate PAI-1 gene expression in vitro and that may explain relationship between PAI-1 and diabetes [8], but this relationship is largely explained by metabolic syndrome.

Some studies found that PAI-1 level is linked to android fat distribution and endocrines and metabolic features of metabolic syndrome [4] [5] [25].

People who have Metabolic syndrome with or without diabetes had elevated PAI-1 level [3] [24] improvement of metabolic syndrome with weight loss decrease PAI-1 level [13].

Some studies had found higher PAI-1 level in people with hypertension [26].

In our study, we didn't find significant difference between mean PAI-1 level of diabetic patients who have hypertension and diabetics without hypertension.

Pronounced elevations of PAI-1 antigen levels were seen in $4 \mathrm{G}$ carriers of $-6754 \mathrm{G} / 5 \mathrm{G}$ polymorphism of T2D patients in a large number of studies, [4] as 
well as non-diabetic and in different ethnic populations like Tunisians [27] [28] [29].

The most significant variation in PAI-1 expression resides in the PAI-1 4G/5G alleles. Unlike the $5 \mathrm{G}$ allele that binds a transcription repressor, resulting in low PAI-1 expression, the $4 \mathrm{G}$ allele does not bind a transcription repressor, thus conferring a "high PAI-1 expressor" nature to the allele I [30].

Martinez-Calatrava [31], had found that $4 \mathrm{G}$ allele is the principal determinant of PAI-1 level in study of 631 persons, independent of metabolic disorders.

These results are in agreements with our study who shown that $-6754 \mathrm{G} / 5 \mathrm{G}$ polymorphism not metabolic disorders was the principal determinant of PAI-1 level. Another study show metabolic syndrome components explain only $12 \%$ of PAI-1variability in T2D patients [4].

$4 \mathrm{G}$ allele has been shown as a risk factor in cardio vascular disease in some studies [32] not others [6], some studies show $4 \mathrm{G}$ as a risk factor of diabetes [33] [34], some studies show $4 \mathrm{G}$ allele association with obesity [35] [36] and metabolic syndrome [37] [38].

About second polymorphism $-844 \mathrm{G} / \mathrm{A}$, we don't found relationship between this polymorphism and PAI-1 level, this results is in agreement with the literature [11] [12] [27].

A Mexican study revealed a relationship between $-844 \mathrm{G} / \mathrm{A}$ and metabolic syndrome [39]. Another study revealed an association with cardio-vascular disease and dyslipidemia [40].

\section{Conclusion}

The present study identifies -675 4G/5G not -844 G/A polymorphism of PAI gene as the principal determinant of plasma PAI- 1 level in adult type 2 diabetes patients in Tunisia, and the android fat distribution, dyslipidemia and hyperglycemia play a modest role in this variation.

\section{Conflicts of Interest}

All authors declare no conflicts of interest.

\section{Author's Participation}

All authors had participated actively in manuscript realization.

\section{References}

[1] Beckman, J.A., Creager, M.A. and Libby, P. (2002) Diabetes and Atherosclerosis: Epidemiology, Pathophysiology, and Management. JAMA, 287, 2570-2581. https://doi.org/10.1001/jama.287.19.2570

[2] Chmielewska, J., Ranby, M. and Wiman, B. (1983) Evidence for a Rapid Inhibitor to Tissue Plasminogen Activator in Plasma. Thrombosis Research, 31, 427-436. https://doi.org/10.1016/0049-3848(83)90407-3

[3] Juhan-Vague, I., Alessi, M.C. and Morange, P.E. (2000) Hypofibrinolysis and Increased PAI-1 Are Linked to Atherothrombosis via Insulin Resistance and Obesity. 
Annals of Medicine, 32, 78-84.

[4] Aburto-Mejia, E., Santiago-German, D., Martinez-Marino, M., Maria Eugenia, G.-P., Almeida-Gutierrez, E., et al. (2017) Hypofibrinolytic State in Subjects with Type 2 Diabetes Mellitus Aggravated by the Metabolic Syndrome before Clinical Manifestations of Atherothrombotic Disease. BioMed Research International, 2017, Article ID: 6519704. https://doi.org/10.1155/2017/6519704

[5] Kohler, H.P. and Grant, P.J. (2000) Plasminogen-Activator Inhibitor Type 1 and Coronary Artery Disease. The New England Journal of Medicine, 342, 1792-1801. https://doi.org/10.1056/NEJM200006153422406

[6] Ding, J., Nicklas, B.J., Fallin, M.D., de Rekeneire, N., Kritchevsky, S.B., et al. (2006) Plasminogen Activator Inhibitor Type 1 Gene Polymorphisms and Haplotypes Are Associated with Plasma Plasminogen Activator Inhibitor Type 1 Levels but Not with Myocardial Infarction or Stroke. American Heart Journal, 152, 1109-1115. https://doi.org/10.1016/j.ahj.2006.06.021

[7] Mansfield, M.W., Stickland, M.H. and Grant, P.J. (1995) Environmental and Genetic Factors in Relation to Elevated Circulating Levels of Plasminogen Activator Inhibitor-1 in Caucasian Patients with Non-Insulin-Dependent Diabetes Mellitus. Thrombosis and Haemostasis, 74, 842-847.

[8] Panahloo, A., Mohamed-Ali, V., Lane, A., Green, F., Humphries, S.E., et al. (1995) Determinants of Plasminogen Activator Inhibitor 1 Activity in Treated NIDDM and Its Relation to a Polymorphism in the Plasminogen Activator Inhibitor 1 Gene. Diabetes, 44, 37-42. https://doi.org/10.2337/diab.44.1.37

[9] Kathiresan, S., Gabriel, S.B., Yang, Q., Lochner, A.L., Larson, M.G., et al. (2005) Comprehensive Survey of common genetic Variation at the Plasminogen Activator Inhibitor-1 Locus and Relations to Circulating Plasminogen Activator Inhibitor-1 Levels. Circulation, 112, 1728-1735. https://doi.org/10.1161/CIRCULATIONAHA.105.547836

[10] Morange, P.E., Henry, M., Tregouet, D., Granel, B., Aillaud, M.F., et al. (2000) The A-844G Polymorphism in the PAI-1 Gene Is Associated with a Higher Risk of Venous Thrombosis in Factor V Leiden caRriers. Arteriosclerosis, Thrombosis, and Vascular Biology, 20, 1387-1391. https://doi.org/10.1161/01.ATV.20.5.1387

[11] Grubic, N., Stegnar, M., Peternel, P., Kaider, A. and Binder, B.R. (1996) A Novel G/A and the 4G/5G Polymorphism within the Promoter of the Plasminogen Activator Inhibitor-1 Gene in Patients with Deep Vein Thrombosis. Thrombosis Research, 84, 431-443. https://doi.org/10.1016/S0049-3848(96)00211-3

[12] Henry, M., Chomiki, N., Scarabin, P.Y., Alessi, M.C., Peiretti, F., et al. (1997) Five Frequent Polymorphisms of the PAI-1 Gene: Lack of Association between Genotypes, PAI Activity, and Triglyceride Levels in a Healthy Population. Arteriosclerosis, Thrombosis, and Vascular Biology, 17, 851-858.

https://doi.org/10.1161/01.ATV.17.5.851

[13] Sola, E., Vaya, A., Espana, F., Castello, R., Ramon, L.A., et al. (2008) Plasminogen Activator Inhibitor-1 Levels in Severe and Morbid Obesity. Effect of Weight Loss and Influence of 4G/5G Polymorphism. Thrombosis Research, 122, 320-327. https://doi.org/10.1016/j.thromres.2007.10.016

[14] Nagi, D.K., McCormack, L.J., Mohamed-Ali, V., Yudkin, J.S., Knowler, W.C., et al. (1997) Diabetic Retinopathy, Promoter (4G/5G) Polymorphism of PAI-1 Gene, and PAI-1 Activity in Pima Indians with Type 2 Diabetes. Diabetes Care, 20, 1304-1309. https://doi.org/10.2337/diacare.20.8.1304

[15] Naran, N.H., Chetty, N. and Crowther, N.J. (2008) The Influence of Metabolic Syn- 
drome Components on Plasma PAI-1 Concentrations Is Modified by the PAI-1 4G/5G Genotype and Ethnicity. Atherosclerosis, 196, 155-163.

https://doi.org/10.1016/j.atherosclerosis.2007.03.024

[16] Xu, F., Liu, H. and Sun, Y. (2016) Association of Plasminogen Activator Inhibitor-1 Gene Polymorphism and Type 2 Diabetic Nephropathy. Renal Failure, 38, 157-162. https://doi.org/10.3109/0886022X.2015.1089464

[17] Festa, A., D'Agostino Jr, R., Tracy, R.P. and Haffner, S.M. (2002) Elevated Levels of Acute-Phase Proteins and Plasminogen Activator Inhibitor-1 Predict the Development of Type 2 Diabetes: The Insulin Resistance Atherosclerosis Study. Diabetes, 51, 1131-1137. https://doi.org/10.2337/diabetes.51.4.1131

[18] Festa, A., Williams, K., Tracy, R.P., Wagenknecht, L.E. and Haffner, S.M. (2006) Progression of Plasminogen Activator Inhibitor-1 and Fibrinogen Levels in Relation to Incident Type 2 Diabetes. Circulation, 113, 1753-1759. https://doi.org/10.1161/CIRCULATIONAHA.106.616177

[19] Kanaya, A.M., Wassel Fyr, C., Vittinghoff, E., Harris, T.B., Park, S.W., et al. (2006) Adipocytokines and Incident Diabetes Mellitus in Older Adults: The Independent Effect of Plasminogen Activator Inhibitor 1. Archives of Internal Medicine, 166, 350-356. https://doi.org/10.1001/archinte.166.3.350

[20] Meigs, J.B., O'Donnell, C.J., Tofler, G.H., Benjamin, E.J., Fox, C.S., et al. (2006) Hemostatic Markers of Endothelial Dysfunction and Risk of Incident Type 2 Diabetes: The Framingham Offspring Study. Diabetes, 55, 530-537. https://doi.org/10.2337/diabetes.55.02.06.db05-1041

[21] Davidson, M., Zhu, J., Lu, W., Tracy, R.P., Robbins, D.C., et al. (2006) Plasminogen Activator Inhibitor-1 and the Risk of Type 2 Diabetes Mellitus in American Indians: the Strong Heart Study. Diabetic Medicine, 23, 1158-1159. https://doi.org/10.1111/j.1464-5491.2006.01923.x

[22] Tani, S., Takahashi, A., Nagao, K. and Hirayama, A. (2015) Effect of Dipeptidyl Peptidase-4 Inhibitor, Vildagliptin on Plasminogen Activator Inhibitor-1 in Patients with Diabetes Mellitus. American Journal of Cardiology, 115, 454-460. https://doi.org/10.1016/j.amjcard.2014.11.044

[23] Yarmolinsky, J., Bordin Barbieri, N., Weinmann, T., Ziegelmann, P.K., Duncan, B.B., et al. (2016) Plasminogen Activator Inhibitor-1 and Type 2 Diabetes: A Systematic Review and Meta-Analysis of Observational Studies. Scientific Reports, 6, 17714. https://doi.org/10.1038/srep17714

[24] Al-Hamodi, Z., Ismail, I.S., Saif-Ali, R., Ahmed, K.A. and Muniandy, S. (2011) Association of Plasminogen Activator Inhibitor-1 and Tissue Plasminogen Activator with Type 2 Diabetes and Metabolic Syndrome in Malaysian Subjects. Cardiovascular Diabetology, 10, 23. https://doi.org/10.1186/1475-2840-10-23

[25] Sartori, M.T., Vettor, R., De Pergola, G., De Mitrio, V., Saggiorato, G., et al. (2001) Role of the 4G/5G Polymorphism of PaI-1 Gene Promoter on PaI-1 Levels in Obese Patients: Influence of Fat Distribution and Insulin-Resistance. Thrombosis and Haemostasis, 86, 1161-1169.

[26] Margaglione, M., Cappucci, G., d'Addedda, M., Colaizzo, D., Giuliani, N., et al. (1998) PAI-1 Plasma Levels in a General Population without Clinical Evidence of Atherosclerosis: Relation to Environmental and Genetic Determinants. Arteriosclerosis, Thrombosis, and Vascular Biology, 18, 562-567. https://doi.org/10.1161/01.ATV.18.4.562

[27] Ezzidi, I., Mtiraoui, N., Chaieb, M., Kacem, M., Mahjoub, T., et al. (2009) Diabetic Retinopathy, PAI-1 4G/5G and -844G/A Polymorphisms, and Changes in Circulat- 
ing PAI-1 Levels in Tunisian Type 2 Diabetes Patients. Diabetes \& Metabolism, 35, 214-219. https://doi.org/10.1016/j.diabet.2008.12.002

[28] Saidi, S., Slamia, L.B., Mahjoub, T., Ammou, S.B. and Almawi, W.Y. (2007) Association of PAI-1 4G/5G and -844G/A Gene Polymorphism and Changes in PAI-1/tPA Levels in Stroke: A Case-Control Study. Journal of Stroke and Cerebrovascular Diseases, 16, 153-159. https://doi.org/10.1016/j.jstrokecerebrovasdis.2007.02.002

[29] Abboud, N., Ghazouani, L., Saidi, S., Ben-Hadj-Khalifa, S., Addad, F., et al. (2010) Association of PAI-1 4G/5G and -844G/A Gene Polymorphisms and Changes in PAI-1/Tissue Plasminogen Activator Levels in Myocardial Infarction: A Case-Control Study. Genetic Testing and Molecular Biomarkers, 14, 23-27. https://doi.org/10.1089/gtmb.2009.0039

[30] Eriksson, P., Kallin, B., van't Hooft, F.M., Bavenholm, P. and Hamsten, A. (1995) Allele-Specific Increase in Basal Transcription of the Plasminogen-Activator Inhibitor 1 Gene Is Associated with Myocardial Infarction. Proceedings of the National Academy of Sciences USA, 92, 1851-1855. https://doi.org/10.1073/pnas.92.6.1851

[31] Martinez-Calatrava, M.J., Martinez-Larrad, M.T., Zabena, C., Gonzalez-Sanchez, J.L., Fernandez-Perez, C., et al. (2007) The 4G/4G PAI-1 Genotype Is Associated with Elevated Plasma PAI-1 Levels Regardless of Variables of the Metabolic Syndrome and Smoking Status. A Population-Based Study in Spanish Population. Diabetes, Obesity and Metabolism, 9, 134-135. https://doi.org/10.1111/j.1463-1326.2006.00584.x

[32] Morange, P.E., Saut, N., Alessi, M.C., Yudkin, J.S., Margaglione, M., et al. (2007) Association of Plasminogen Activator Inhibitor (PAI)-1 (SERPINE1) SNPs with Myocardial Infarction, Plasma PAI-1, and Metabolic Parameters: The HIFMECH Study. Arteriosclerosis, Thrombosis, and Vascular Biology, 27, 2250-2257. https://doi.org/10.1161/ATVBAHA.107.149468

[33] Zhang, T., Pang, C., Li, N., Zhou, E. and Zhao, K. (2013) Plasminogen Activator Inhibitor-1 4G/5G Polymorphism and Retinopathy Risk in Type 2 Diabetes: A Meta-Analysis. BMC Medicine, 11, 1. https://doi.org/10.1186/1741-7015-11-1

[34] Al-Hamodi, Z., Saif-Ali, R., Ismail, I.S., Ahmed, K.A. and Muniandy, S. (2012) Effect of Plasminogen Activator Inhibitor-1 and Tissue Plasminogen Activator Polymorphisms on Susceptibility to Type 2 Diabetes in Malaysian Subjects. Journal of Biomedicine and Biotechnology, 2012, Article ID: 234937. https://doi.org/10.1186/1741-7015-11-1

[35] Hoffstedt, J., Andersson, I.L., Persson, L., Isaksson, B. and Arner, P. (2002) The Common -675 4G/5G Polymorphism in the Plasminogen Activator Inhibitor-1 Gene Is Strongly Associated with Obesity. Diabetologia, 45, 584-587. https://doi.org/10.1007/s00125-001-0774-5

[36] De la Cruz-Mosso, U., Munoz-Valle, J.F., Salgado-Bernabe, A.B., Castro-Alarcon, N., Salgado-Goytia, L., et al. (2013) Body Adiposity But Not Insulin Resistance Is Associated with -675 4G/5G Polymorphism in the PAI-1 Gene in a Sample of Mexican Children. Jornal de Pediatria, 89, 492-498. https://doi.org/10.1007/s00125-001-0774-5

[37] Bouchard, L., Mauriege, P., Vohl, M.C., Bouchard, C. and Perusse, L. (2005) Plasminogen-Activator Inhibitor-1 Polymorphisms Are Associated with Obesity and Fat Distribution in the Quebec Family Study: Evidence of Interactions with Menopause. Menopause, 12, 136-143. https://doi.org/10.1097/00042192-200512020-00006

[38] Al-Hamodi, Z.H., Saif-Ali, R., Ismail, I.S., Ahmed, K.A. and Muniandy, S. (2012) Plasminogen Activator Inhibitor-1 4G/5G Polymorphism Is Associated with Meta- 
bolic Syndrome Parameters in Malaysian Subjects. Journal of Clinical Biochemistry and Nutrition, 50, 184-189. https://doi.org/10.3164/jcbn.11-48

[39] De la Cruz-Mosso, U., Munoz-Valle, J.F., Salgado-Goytia, L., Garcia-Carreon, A., Illades-Aguiar, B., et al. (2012) Relationship of Metabolic Syndrome and Its Components with -844 G/A and HindIII C/G PAI-1 Gene Polymorphisms in Mexican Children. BMC Pediatrics, 12, 41. https://doi.org/10.1186/1471-2431-12-41

[40] Garcia-Gonzalez, I.J., Valle, Y., Sandoval-Pinto, E., Valdes-Alvarado, E., Valdez-Haro, A., et al. (2015) The -844 G>A PAI-1 Polymorphism Is Associated with Acute Coronary Syndrome in Mexican Population. Disease Markers, 2015, Article ID: 460974. https://doi.org/10.1155/2015/460974

Submit or recommend next manuscript to SCIRP and we will provide best service for you:

Accepting pre-submission inquiries through Email, Facebook, LinkedIn, Twitter, etc. A wide selection of journals (inclusive of 9 subjects, more than 200 journals)

Providing 24-hour high-quality service

User-friendly online submission system

Fair and swift peer-review system

Efficient typesetting and proofreading procedure

Display of the result of downloads and visits, as well as the number of cited articles

Maximum dissemination of your research work

Submit your manuscript at: http://papersubmission.scirp.org/

Or contact ojemd@scirp.org 